\title{
EL NOMBRE PROPIO COMO IMAGEN SEMIÓTICA DEL REFERENTE
}

\author{
LUIS SÁNCHEZ CORRAL \\ (Universidad de Córdoba)
}

\section{La existencia lingüística de las marcas comerciales.}

Que la marca o firma comercial constituyen, en la economía de producción para el mercado, un concepto económico de trascendencia objetiva en la actividad funcional del sistema empresarial, es algo que no admite ningún género de duda, sea cual sea el punto de vista teórico adoptado en la planificación técnica de la industria y del consumo. La propia estructuración interna de las empresas acusa ineludiblemente las determinaciones que impone el concepto económico referido y así se refleja en la existencia de departamentos específicos dedicados, precisamente, a planificar, ejecutar y promocionar las marcas o firmas de las mercancias. Sin embargo, lo que nos interesa en este trabajo es indagar de qué modo, a través de la textualización del nombre propio en la práctica del discurso publicitario, la marca comercial necesita ser un concepto lingüístico para funcionar como concepto económico regulador, en no escasa medida, de la actividad del mercado:

Efectivamente, las firmas comerciales se lanzan a la conquista del mercado mediante el impacto que produce la presencia insistente del nombre propio del producto en los medios de comunicación de masas, cuya dimensión más radical estaría representada por la reducción —que se da en múltiples ocasiones- de la demanda comercial al Nombre y por la inscripción de éste en el registro de la propiedad privada. No vamos a insistir nosotros en la confirmación de este principio

'Una rigurosa y amplia demostración de la actividad reguladora del mercado ejercida por la publicidad, que es en definitiva el vehículo imprescindible para la difusión del nombre propio de la marca, puede verse en J. R. Sánchez Guzmán: «Teoría económica de la publicidad», en Introducción a la teoría de la publicidad, Madrid, Tecnos, 1979, pp. 222-352. El mismo autor describe, en otro ilustrativo trabajo, la inserción de las actividades publicitarias en el interior del organigrama y del sistema empresarial. Cf. Teoria general del sistema publicitario, Madrid, Forja, 1981. 
del marketing, pues, hace ya algunos años ${ }^{2}$, el semiólogo francés G. Péninou demostró de una forma irrebatible que uno de los objetivos decisivos de la publicidad se cifra en conquistar los mercados mediante la «autoridad exclusiva del Nombre Propio». Desde el punto de vista semiótico, lo que nos debe preocupar esencialmente es averiguar por qué razones el rendimiento de la actividad comercial necesita de una operación lingüística que designe individualmente a los productos y les confiera una identidad particularizante, una identidad que los promocione adecuadamente y los introduzca en la memoria de los receptores de los mensajes.

\section{El nombre propio, identidad de la mercancía.}

La trascendencia de asignar un nombre —y más un nombre propio- a los objetos que carecen de él ha sido unánimamente puesta de manifiesto por los investigadores antropológicos para todo tipo de culturas, incluidas las agrupaciones tribales más elementales. Incluso sin salirnos de la disciplina de la semiótica, la escuela soviética de Tartú equipara el acto de nombrar con un «acto de creación, de reencarnación o renacimiento» que le otorga al nombre propio una confluencia significativa con el estrato de la mitología:

«Esta identificación del nombre y de la cosa nombrada determina, a su vez, la idea del carácter no convencional de los nombres propios y de su naturaleza ontológica $x^{3}$.

Se apunta aquí la idea de que el sistema de la denominación individualizadora es algo más que una simple y abstracta operación del sistema linguiístico. No está de más, por tanto, recordar las reflexiones de $\mathrm{R}$. Jakobson al respecto, quien le atribuye a los nombres propios un lugar específico en el código lingüístico ${ }^{4}$. Y es que la nominación de las cosas las instala ya en su propia existencia. Pero, si además este acto nominativo se presenta y se divulga en los medios de comunicación de masas, ocurre lo que dice Moragas $\mathrm{Spa}^{5}$, que las cosas se tiñen de euforia y se patentizan todavía más. No es exagerado, entonces, inferir que en nuestros días, por lo menos en el reducto del lenguaje publicitario, los nombres propios conservan a través de la «imagen de marca» esa aureola de poderes mágicos y de elaboradas supersticiones y tabúes de que nos habla Ullmann, al tratar este problema. Para ello rastrea en Homero o en Shakespeare la conjunción que se establece entre el nombre propio y la reputación de la fama de la persona que lo lleva ${ }^{6}$.

\footnotetext{
${ }^{2}$ Nos estamos refiriendo al trabajo «Le oui, le nom et le caractère», en Les mythes de la publicité, Communications, 17, París, 1971, pp. 67-81; posteriormente incorporadoen Semiología de la publicidad, Barcelona, Gustavo Gili, 1976 (título original Inteligence de la Publicité. Étude sémiotique, París, Editions Robert Laffont, S. A., 1972).

3. M. Lotman y B.A.Uspenskij: «Mito, nombre, cultura», en Semiótica de la cultura, Madrid, Cátedra, 1979, p. 117.

${ }^{4}$ Ct., específicamente, «Les embrayeurs, les catégories verbales et le verbe russe», en Essais de linguistique générale, París, Minuit, 1963, pp. 176-206.

'Semiótica y comunicación de masas, Barcelona, Península, 1976, p. 162.

' Semántica, Madrid, Aguilar, 1976, p. 82.
} 
Las concepciones mitológicas, antropológicas o rituales de que disfruta el nombre propio, aplicadas a las marcas publicitarias, nos permiten asegurar con G. Péninou la trascendencia de la denominación de los productos como inserción de la Materia en la categoría de la Persona:

«El paso de la economía de producción a la economía comercial del mercado de marca, no es sólo el paso de lo innombrado a lo nombrado. Es también el paso del realismo de la Materia (el nombre común) al simbolismo de la Persona (el nombre propio). Todo el discurso antropocéntrico que la publicidad hace respecto a los objetos resulta concebible por la mediación de la marca, que hace penetrar al objeto en el circuito de la persona, porque la marca es a menudo tratada también como analogía de la persona. Además sólo la persona o su asimilado puede recibir la consagración del nombre propio» ${ }^{7}$.

Tal es la primera operación básica de la persuasión: otorgarle capacidad e identidad individual a la mercancía. Esto ha de ser así porque el ritual de «bautizo» de los productos debe ser previo, en tanto en que confiere una existencia en el ámbito de lo social, a la atribución de los demás valores asignados por las estructuras lingüísticas y semióticas.

Claro que la coherencia que cohesiona la construcción discursiva de la publicidad encierra en sí misma una contrapartida peligrosa:

«Por supuesto, una «cosa» no existe socialmente más que si es denominadas, y sin embargo, el que transforma este enunciado en ley y en reglamento autoritario realiza la operación más peligrosa, la que legitima el poder absoluto; este poder pertenecerá a aquel que «nombra» ${ }^{8}$.

Dejando aparte otros discursos muy específicos, donde «aquel que nombra» puede ser o bien la Divinidad - como sucede en la palabra bíblica o en las lecturas brahamanas - o bien el Príncipe de las monarquías absolutas, en la enunciación publicitaria «aquel que nombra» pertenece al ámbito del destinador, cuyo poder actancial y enunciativo desempaña, para que resulte eficaz su discurso y su acto denominativo, un hacer manipulador unidireccional, ya que habla omnisciente y subjetivamente desde los intereses comerciales y semióticos específicos de la marca anunciada.

La imposición del logotipo o de la marca adquiere en la publicidad la dimensión mágica de todo acto bautismal. Hasta tal extremo que la marca y el logotipo terminan por ser, en múltiples ocasiones, la razón misma de la publicidad, el resumen linguístico del producto y el factor diferencial frente a sus competidores. En consecuencia, esta síntesis nominal acapara el fundamento mismo del lenguaje publicitario y actúa de elemento organizador y estructurante de la composición del anuncio. Como tal síntesis nuclear, la marca está destinada a perdurar en la memoria de los receptores, lo que explica el hecho de que sea el único segmento lingüístico

${ }^{7}$ Semiótica de la publicidad, pp. 90-91.

${ }^{8}$ H. Lefebvre: La vida cotidiana en el mundo moderno, Madrid, Alianza Editorial, 1968, p. 151. 
al que se le otorga, simultáneamente, una existencia también icónica. De ahí el funcionamiento de lo que podríamos denominar retórica de las grafías, mediante la transformación de la materialidad verbal en materialidad visual". Sin duda, estos rasgos definidores impulsan a los publicitarios a reiterar sistemáticamente la presencia del nombre propio en cualquier lugar del anuncio. Buena prueba de ello es la importancia que la industria del sector le otorga a grafistas y dibujantes ${ }^{10}$. La razón de este carácter nuclear del nombre propio hay que buscarla en la doble producción de sentidos que genera. José Saborit señala al respecto:

«De un lado, el logotipo y la marca en tanto síntesis visual del objeto, actúan como referentes del anuncio, en representación del producto. De otro, al ser percibidos en el soporte del objeto real —cuando éste se encuentra en el lugar de la compra—, remiten al mensaje publicitario, que adopta sus imágenes generaimente como broche final»" ${ }^{1}$.

Todos estos rasgos que definen la dimensión esencial del proceso virtualizante de la denominación vienen confirmados por la praxis concreta publicitaria. Así, la firma MICHELÍN confecciona la promoción de sus neumáticos centralizando la composición global del anuncio y sus diversas partes en torno al nombre propio:

a) Titular: «PÍDALOS POR SU NOMBRE PROPIO»

b) Presentación predicativa: «El nombre de Michelín se asocia en todo el mundo al de un neumático de primera calidad, fiable, seguro. Lo que se dice una gran marca, un gran nombre.

Por eso, a la hora de comprar numáticos, no diga: «Cámbieme las ruedas». Diga: «Quiero que me pongan Michelín».

c) Argumentación: «Porque a usted le pueden montar en su coche cualquier neumático, quizá algo más barato, quizá con un poco de descuento. Pero siempre saldrá ganando si le montan neumáticos con un gran nombre: MICHELÍN».

d) Conclusión: «Concrete su petición, PÍDALOS POR SU NOMBRE»

e) Cierre: «MICHELÍN».

\section{El nombre propio, elemento nuclear del anuncio.}

Las autorreflexiones metalinguísticas contenidas en el anterior manifiesto de MICHELÍN pudieran inducir a pensar que, aunque hábilmente manejadas por el enunciador, constituyen algo excepcional en la comunicación publicitaria y que, por

"La aplicación a los enunciados publicitarios de los tres componentes que diferencia B. Pottier en el interior de los mensajes (el verbal el gráfico y el icónico) y de sus correspondientes variables connotativas o denotativas posibilitaría, sin duda, documentar ampliamente las caracterizaciones que estamos señalando. Cf. «Le graphémique et l'iconique dans le massage», en Toos Steele \& Terry Treadgol (eds.): Language Topics, Essays in honour of Michael Halliday, Amsterdam/Philadelphia, 1987, pp. 305-307.

17. J. Llorente, uno de los creativos publicitarios más importantes del sector español, explica la expresividd de las diversas tipografías y los requisitos que éstas han de tener para probar su eficacia (Cf. Casi todo lo que sé de la publicidad, Barcelona, Folio, 1986).

"La imagen publicitaria en televisión, Madrid, Cátedra, 1988, pp. 85-86. 
lo tanto, responden a un hallazgo creativo de la intuición del «textista» más que a los plantemientos sistemáticos que venimos sosteniendo. Justamente para deshacer estas posibles objeciones nos proponemos examinar, en lo que constituye el núcleo del presente trabajo, algunas técnicas enunciativas practicadas con asiduidad y conscientemente calculadas por los eficientes departamentos «creativos» de las agencias de publicidad. Así, entre otras posibles, describiremos las siguientes: (3.1.) autorreferencias artísticas de la firma comercial, (3.2) la exhibición esencialista, (3.3) las ornamentaciones retóricas, (3.4.) la estructura tautológica de los anuncios. En el mismo orden de cosas y a fin de diversificar nuestras fuentes de argumentación, aduciremos también (3.5) datos «profesionales» sobre el propio concepto de marca y (3.6.) datos estadísticos extraídos de un corpus de 728 anuncios.

\subsection{Autorreferencias artísticas de la firma comercial.}

Los recursos mediante los que la publicidad llama la atención sobre el nombre propio de la marca son ilimitados, pero destacan, como hemos anticipado ya, las referencias a la propia firma comercial. El mencionado caso de MICHELÍN es significativo al respecto, lo mismo que las siguientes reflexiones autorreferen-ciales qu sugiere la marca WHITE HORSE, cuyo leitmotiv consiste en demostrar metalingüísticamente su consigna «EL ESCOCÉS DE LOS ESCOCESES».

«En Escocia, blanco se dice white

y caballo se dice horse. Por eso los

escoceses para pedir su whisky

preferido, en lugar de caballo blanco, piden White Horse

$Y$ aquí, cuando quiera un gran

whisky, busque el caballo blanco

y pídalo como un auténtico escocés

White Horse, please!.»

Estas autorreferencias adquieren una significativa frecuencia en el terreno de la moda, cuyo argumento más reiterado es la invitación al cliente para entrar en «un mundo de exclusivas», «un mundo donde la moda tiene nombre propio, porque lleva la firma de unos grandes creadores cuya fama no conoce fronteras», y donde «los auténticos genios del diseño dan nombre a una moda que no tiene nadie. Sólo las Boutiques Internacionales de EL CORTE INGLES». Se trata de insistir recurrentemente en la exclusividad de la firma, en el genio creador, en la autoría de la creación.

Se puede definir esta operación publicitaria como una paráfrasis (paródica, desde luego) de la creación artística, sobre todo en cuanto a la concepción idealizada del «genio» individualista y creador, que sitúa el énfasis fundamental en la permanencia definitiva del nombre del «autor». La importancia actual de la firma y del diseño representa la manifestación más palpable de lo que decimos. La publicidad 
en este punto concreto, como en tantos otros, asume determinadas conquistas formales y determinadas mixtificaciones del fenómeno estético.

Sin entrar ahora en un estudio detenido sobre la utilización interesada que, con fines persuasivos, la publicidad hace de las manifestaciones y de los contenidos artísticos, como particulares formaciones isotópicas que configuran parte del universo semántico del discurso, es conveniente dejar sentado, al menos, el paralelismo que se observa entre el sentido con que el arte usa el nombre propio del autor-artista y el aprovechamiento manipulador que del nombre propio hace la publicidad.

Esta mixtificación que el lenguaje de las mercancías hace del arte puede apreciarse claramente en un amplio y significativo número de anuncios que utilizan o bien las tendencias abstractas o las tendencias «naif» de las formas pictóricas. Pueden servir como ilustrativos ejemplos respectivos de lo que decimos la firma de relojes LASSALE y una reciente campaña de promoción de la firma COINTREAU.

En el primero de los casos, y bajo la inequívoca directriz del slogan «CREAR HOY PARA SIEMPRE», se acude a la representación pictórica - real o simulada, poco importa para los efectos provocados-de Antoni Clavé «Collage sur Alu. Collage sobre alumnio. $78 \times 66 \mathrm{~cm}$. Colección privada Lassale».

En el segundo de los ejemplos propuestos, se intensifican, si cabe, los efectos expresivos, porque ahora la etiqueta-signo de la bebida y el producto mismo están integrados en el interior de la «obra de arte», una «obra de arte» específicamente creada para la ocasión publicitaria con la indicación del «prestigioso» título idiomático L'heure du Cointreau. Como sucedía en el reclamo anterior, también aquí se contextualiza con afán documentalista la representación creada: Juan Romero. Madrid 1989. COLECCIÓN COINTREAU DE ARTE CONTEMPORÁNEO». Se trata, en ambas circunstancias, de imprimir una cierta aureola de verosimilitud sobre el valor añadido de las firmas individualizadas como firmas artísticas.

El mensaje a transmitir es, indudablemente, bien claro: las mercancías no son productos económicos, sino auténticas obras de arte, porque sus fabricantes no son fabricantes, sino creadores artísticos con una firma ya consolidada. La generación de significados - indudablemente preconcebidos- se establece por analogía metonímica entre el nombre-signo de la marca y el cuadro abgstracto o el cuadro naif, entre los objetos comerciales y los titulares-slogan, entre la contigüidad del consumidor y el objeto consumido (o, cuando menos, deseado).

Tales aplicaciones subsidiarias y fetichistas de la creación estética, en la medida en que el arte se utiliza como estrategia persuasivo-manipuladora, han sido explícitamente reconocidas por los propios responsables de las empresas anunciadoras. De este modo explica, en declaraciones internas, la agencia FIGUEROLA-FERRETI las reproducciones falsificadas de Velázquez o de Picasso empleadas para promocionar la firma GASTON Y DANIELA: «Dado el creciente interés del público por el arte en general, y muy especialmente por la pintura, ideamos una campaña basada en la recreación de cuadros clásicos fácilmente identificables por todoel mundo ${ }^{12}$. Podríamos multiplicar las declaraciones técnicas,

${ }^{12}$ Campaña, Madrid, Ediciones Campaña S.A., 1989, p. 180. 
que tenemos abundantemente documentadas, acerca de la intencionalidad mixtificadora y manipuladora con que los publicistas acuden a los contenidos artísticos o culturales. Sean suficientes, no obstante, las motivaciones siguientes:

«En una época marcadamente consumista, la cultura de lo urbano ha trasladado la idea de arte a la calle, fuera de los museos. Objetos tremendamente cotidianos han adquirido auténtico valor artístico. Ceniceros, percheros, teteras, bolígrafos, sillas, sillones, puentes, naves industriales son hoy muestras reconocidas de arte moderno. Los diseñadores son artistas. Y los artistas diseñan. El diseño que viste la tecnología puntera de los televisores Cubic de Sanyo es una muestra más de esta avanzada concepción de hacer del arte un objeto útil $\gg^{13}$.

Los dos anuncios que reproducimos a continuación todavía van más allá en el intento de identificar la mercancía con el arte, puesto que lo que se pretende es identificar cualitativamente el nombre propio del producto con el artista creador:

(i) «Todas las posibilidades de disfrutar de la música [...]

Disfrute las obras de un gran compositor: THOMSON [...]

Le ofrecemos las grandes posibilidades de un maestro de la música. ALTA FIDELIDAD POR TODO LO ALTO».

ii) «GRANDES NOMBRES ALEMANES DE LA MUSICA

Beethoven

Mozart

Wagner

SABA

Con perdón. «Ellos hicieron la música. SABA le permite escucharla mejor [...] EL QUE SABE, SABA».

Como puede observarse fácilmente, el señuelo mixtificafor del arte hace uso de los argumentos tópicos de la «estilística» del Kitsch ${ }^{14}$, al intentar reafirmar en el cliente potencial un sentimiento cultural de praxis artística sobre el universo original de la pintura o de la música, cuando en realidad se trata de una representación ilusoria o de una imitación o copia secundaria de la creación primitiva. Sin embargo, esta «estilística» del Kitsch funciona con extraordinario rendimiento en la cultura -0 subcultura-de masas, porque, desde tales presupuestos, el dilema entre el original y la copia no existe. Solamente así resulta creíble y aceptable publicitariamente identificar al «maestro»Thomson o al «maestro» Saba con Beethoven, Mozarto Wagner.

${ }^{13}$ Ibíd, p. 261.

${ }^{14}$ Los problemas socioculturales que plantea la «estilística» del kitsch han sido tratados con detenimiento por U. Ecoen Apocalipticos e integrados, Barcelona, Lumen, 1981, pp. 73-152. Es asimismo de interés para fijar las características dominantes de este fenómeno propio de la cultura de masas el trabajo de A. Moles y E. Wahl «Kitsch y objeto», en AA.VV.: Los objetos, Buenos Aires, Tiempo Contemporáneo, 1971, pp. 153-186. Una revisión crítica actualizada del problema que plantean las relaciones entre el kitsch y el arte puede vese en J. A. Ramírez: Medios de masas e historia del arte, Madrid, Cátedra, 1988, pp. 259-285. 
Hasta tal punto se produce el trasvase de lenguajes desde las manifestaciones artísticas a la publicidad que, al final, lo que se compra y se vende es una firma, un diseño de una firma, independientemente de los referentes concreto ${ }^{15}$ :

(i) «Tucci. Este es el nombre del diseñador que ha creado una nueva raza de trajes»

(ii) «Grundig. La seguridad de un gran nombre»

(iii) «Por eso no es casualidad que el mayor número de tarjetas con un gran nombre como VISA, lleven un gran apellido como Banco de Bilbao»

(iv) «BAJO EL SIGNO DE IVECO. Una marca europea para el transporte español».

\subsection{La exhibición como esencialidad de la marca.}

El caso límite de este proceso nominalizador se expresa en un tipo de publicidad específica y peculiar, en la que la marca no solamente es la síntesis estructurante del mensaje, sino la esencialización misma de todo el proceso: la marca y el objeto de marca ocupan, en un régimen de ostensión acaparadora, todo el espacio publicitario disponible. La marca y el objeto de marca se exhiben por sí mismos, soberbiamente aislados y sin entornos contextuales, sin anécdotas ni sintaxis. Es el simple registro del nombre propio como sujeto absoluto, como símbolo de la perfección más acabada. Fuera de cualquier contingencia, el receptor se encuentra ante la esencia misma y ante la existencia de lo único.

En esta clase de publicidad ocurre $\ll$ la captación absoluta del Ser por el Objeto ${ }^{16}$, conforme apunta G. Péninou, quien acude a la lingüística para calificar, metafóricamente pero con exactitud, estos anuncios así construidos como publicidad en infinitivo. Siguiendo el paralelismo entre publicidad y lingüística, el semiólogo francés dice que de este modo el producto manifiesta su naturaleza más sustantiva y trascendente. Todas las circunstacias coinciden para afirmar que el receptor se encuentra frente a un mensaje «ontológico»:

«Este mensaje, de un laconismo supremo y que ya no puede ser referencial, no quiere imponerse ni por la ostentación de sus cualidades (no enuncia ninguna) ni por la prodigalidad de su argumentación (que está ausente) ni por el cebo de su envite (se renuncia a él). Ni ofensivo ni opresivo, de una dignidad ejemplar y una distancia

${ }^{15}$ En un reciente artículo de N. Delbecque, K. U. Leuven se insiste en esta puntualización («En la cultura occidental el consumo se ha convertidoen su mayor parte en un rito simbólico»).Cf. «El lenguaje de la publicidad y su poder de sugestión. Anuncios publicados en ElPaís semanal: los tópicos más frecuentes y su formulación», en Lingüistica Española Actual, XII-2, 1990, pp. 197-212.

${ }^{16} \mathrm{G}$. Péninou: op. cit., p. 116. 
calculada, de una solemnidad rebuscada, no solicita el diálogo y desdeña la solución; más allá de lo psicológico, requiere el homenaje, traducción laica de la veneración y postula con altura que se obedezca a su autoridad $»^{17}$.

Tales tipos de anuncios podrían leerse con la ayuda que nos aportan las teorías gramaticales sobre el infinitivo en general y, particularmente, las interpretaciones que de la estructura vebal realizan autores como Lamíquiz o Alarcos, inspirándose en las aportaciones de G. Guillaume (Temps et verbe) y de la lingüística estructural. Ciñéndonos únicamente al punto concreto que tratamos, vemos que el infinitivo representa la posición inicial de la «tersión» con su carga temporal intacta, representado, por tanto, el miembro neutro del paradigma de las llamadas «formas no personales del verbo»:

«El infinitivo, pues, es la forma verbal más general, al expresar el proceso en reposo, sólo como simple presencia realizable. Es la forma virtual por excelencia, la más abstracta, y no en valde es la forma escogida por los diccionarios como representante de la conjugación ${ }^{18}$.

Ahora bien, para que la teoría gramatical sobre el infinitivo resulte aplicable en otro de sus aspectos, es necesario considerar la otra posibilidad del infinitivo, o sea, su capacidad para funcionar como sustantivo:

Pero en ese momento inicial tiene también la posibilidad (el infinitivo) de dirigirse hacia el universo-espacio y de acabar en él, para comportarse como categoría nominal haciéndose discreta o sustantivo ${ }^{19}$.

Esta doble funcionalidad morfosintáctica muestra, por analogía su rendimiento para la «publicidad del infinitivo», porque el objeto de marca, tratado de esta forma, representa el ser publicitario absoluto en tanto que categoría sustantiva, a la vez que el hacer publicitario absoluto en tanto que categoría verbal con todas sus potencialidades en estado de virtualidad. Este tratamiento comunicativo del producto le confiere la competencia para instituirse como sujeto potencial, es decir, como actante motivador de cualquier actividad enunciativa (aunque presentada como empírica) inserta en el interior de los mensajes publicitarios.

La publicidad del Ser absoluto y del Hacer absoluto, en la soledad desafiante del encuadre único y con la mínima presión contextual, viene a cubrir un segmento del mercado bien preciso y delimitado. Justamente el segmento de consumidores caracterizados como autodirigidos y, en particular, aquel sector de más fuerte poder adquisitivo y de status social elevado (o aquel sector que aspira a ingresar en dicho status social elevado (o aquel sector que aspira a ingresar en dicho status social elevado). Y esto a pesar de que los mensajes tiendan a unificar sociológicamente a

${ }^{17}$ lbid., pp. 117-118.

${ }^{18}$ E. Alarcos Llorach, «Sobre la estructura del verbo español», en Estudios de gramática funcional del español, Madrid, Gredos, 1972, p. 60.

${ }^{19}$ V. Lamíquiz: Morfosintaxis estructural del verbo español, Universidad de Sevilla, 1972, pp. 54. 
los consumidores, intentado siempre salvar una de las paradojas clave de la publicidad: cómo aunar el concepto publicitario de «personalidad exclusiva» con las formas colectivas y masificadas que impone, por definición, el acto mismo del consumo. Las marcas y productos que se expresan en el anuncio como únicos e ineludibles suelen aparecer preferentemente en revistas especializadas dirigidas a determinadas profesiones liberales.

\subsection{Ornamentaciones retóricas.}

Desde otro punto de vista, la posición cardinal que el nombre propio ocupa en el sistema del discurso publicitario puede, asimismo, explicar los numerosos recursos retóricos que se generan acumulativamente en torno a la simple presencia de la marca o firma. El motivo parece residir, por una parte, en la necesidad de atraer y concentrar la atención y el interés de los receptores y, por otra, en el recubrimiento «lírico» que las textualizaciones retóricas le otorgan al producto.

En esto también la publicidad aprovecha las experiencias expresivas del proceso «extrañador» del lenguaje poético, Como señaló V. Shklovski $i^{20}$ ya en los mismos orígenes del «formalismo ruso», uno de los procedimientos, entre otros, para que se cumpla el efecto de «extrañamiento» en el lenguaje consiste en su percepción «desautomatizada» a través del carácter imprevisible que le otorgan los artificios retóricos. Pero lejos de establecer una simetría cabal entre la retórica del texto artístico y la del texto publicitario, conviene sentar correctamente las divergencias que la intencionalidad pragmática o los requisitos de la recepción determinan entre ambos tipos de textos. Mientras en el lenguaje literario el alargamiento y la intensificación del proceso de percepción se consigue por la fuerte presencia de una «forma obstruyente» y hermética, en el lenguaje publicitario la intensificación de la recepción «extrañadora» se consigue sin esa forma obstruyente, porque lo que interesa es persuadir por vía directa, sin que se le exija al receptor ninguna dificultad interpretativa. Es decir, si en el arte, como señalan los formalistas rusos, la percepción está orientada hacia el interior del arte mismo, en la publicidad, por el contrario, es prescriptivo afirmar con toda claridad el reconocimiento de las cosas.

Sin embargo, estas divergencias cualitativas no eliminan las correspondencias que puedan descubrirse. La misma metodología empleada por Jakobson para explicar su concepto de función poética, al analizar el slogan político I Like Ike, demuestra no sólo la posibilidad, sino la conveniencia de que los estudios de la función poética rebasen los límites de la poesía ${ }^{21}$. En el clarificador artículo de Lázaro Carreter sobre esta cuestión, se mantiene la teoría de que «la función poética no es exclusivamente poética y, por tanto, no es distintiva $\gg^{22}$. Por ello se sugiere que infinidad de mensajes — publicitarios, religiosos, políticos, legales...- pueden emparentarse, en esta dirección, con el lenguaje artístico.

\footnotetext{
${ }^{20}$ «El arte como artificio» en $\mathrm{T}$. Todorov (comp.): Teoria de la literatura de los formalistas rusos, Buenos Aires, Siglo XXI, 1976, p. 61.

${ }_{21}$ «Linguistique et poetique» en op. cit., pp. 203-248.

${ }_{22}$ «Es poética la función poética?», en Estudios de poética, Madrid, Taurus, 1976, p. 72.
} 
Conscientes de que la organización retórico-persuasiva del discurso abre nuevas perspectivas en la investigación publicitaria y de que, por consiguiente, requerirían un espacio del que no disponemos en este artículo, nos limitamos en este momento a seleccionar unos cuantos ejemplos de artificios retóricos, a fin de ilustrar la posición central que, también en este ámbito, ocupa el nombre propio de la marca, recubriendo todas las operaciones y dominios establecidos por el modelo de «retórica general» del Grupo $\mu^{23}$ :

I. Metaplasmos y metagrafos o modificaciones de las palabras y de los elementos inferiores a la palabra, desde el punto de vista de la expresión tanto fonética como gráfica:

(i) «La copiadora SHARPonesa»

(ii) «MAXIMA CALIDAD = MAXELL»

(iii) «SONY, EL SONYDO SONY»

(iv) «NO compre sin Thom ni Son. THOMSON»

(v) «EL QUE SABE, SABA»

(vi) «TODAGRES. PAVIMENTO DE GRES»

(vii) «Philips día, mamá»

II. Metataxis o transformaciones formales de la estructura de la frase:

(i) «Navidades SONY»

(ii) «Reflejos en Brut»

(iii) «Con más razón J\&B en Navidad»

(iv) «Ya sabes...un vaso, unos hielos y Marie, siempre Marie»

(v) «R19. Furza emergente»

(vi) «CEPSA. El superaceite»

III. Metasememas o modificaciones del significado, desviando los semas denotativos al plano de la connotación:

(i) «El nuevo Citröen. Himno a la alegría»

(ii) «Sierra. La silueta creada por el viento»

(iii) «Multigrado Diesel. El traje para todo el año»

(iv) «Tía María. Una isla de sabor»

(v) «Extraplanos de Citizen. Hojas del tiempo»

IV. Metalogismos o modificaciones del valor lógico de la frase:

(i) «Sálgase de la tónica general. Tónica Kas. Nuestra tónica»

(ii) «Renfe. Un tren de descuentos»

(iii) «BOSCH es un regalo»

${ }^{23}$ Réthorique général, París, Seuil, 1982. 
(iv) «Todo un privilegio. PRIVILEGIO del rey don Sancho»

(v) «Punto por punto. «El mejor jersey. PUNTO BLANCO»

(vi) «Nuestro RITMO GLX. Para tu ritmo de vida»

(vii) «El sabor se ha hecho realidad. Reales. Real sabor negro».

\subsection{La estructura tautológica de los anuncios.}

Antes de pasar a describir la práctica textual y a fin de situar esta nueva técnica para realzar el nombre propio de las marcas publicitarias, parece conveniente examinar, aunque sea brevemente, algunos efectos de sentido ocasionados por la disposición circular de la tautología.

Esta figura lógico-literaria, en tanto que puede ser definida como «una proposición cuyo predicado no añade nada nuevo con respecto al tema ${ }^{24}$ se constituye en una construcción sintáctica y semántica indiscutible, ya que no existe la posibilidad de verificar o de comprobar nada, salvo la aceptabilidad gramatical y semántica de la proposición. En ejemplos como los estudiados por G. Leech («La mujer que amo es del sexo femenino», «Este huérfano no tiene padre» ${ }^{25}$, al establecerse una relación hiponímica entre el argumento y el predicado, la proposición resultante es invariablemente verdadera. Como también hacer ver J. Lyons, las tautologías son, en principio, no informativas, «puesto que una tautología no dice al destinatario nada que éste no sepa ya o no pueda deducir por sí mismo en virtud del conocimiento de la lengua $»^{26}$. El propio Lyons, al indagar las circunstancias en que suele aparecer este tipo de proposiciones, aduce una explicación con la que podemos justificar nosotros su frecuente uso en el discurso de las mercancías:

«Las tautologías pueden enunciarse para expresar algo que el destinatario reconozca como una verdad notoria a fin de que extraiga alguna conclusión pertinente (v. $g r$., «Los negocios son los negocios»). (...) Lo que el destinatario hace, al oír y comprender un enunciado tautológico, es decirse para sus adentros algo así como: «Debe haber alguna razón para que el hablante me diga lo que él ya sabe que conozco. ¿Cuál pude ser esta razón?». El destinatario asume, a menos que algo pruebe lo contrario, que el hablante no esta charlando sin ton ni son» ${ }^{27}$.

Estas palabras de Lyons podrían aplicarse, sin duda alguna, al efecto retórico que pretende la publicidad mediante el uso reiterativo de construcciones tautológicas o similares. Precisamente, el uso reiterativo que se detecta en los anuncios nos ha llevado a plantearnos el valor expresivo de las mismas, en calidad de manifestaciones transparentes con las que el discurso recubre la autoridad enunciativa del actante destinador como autoridad indiscutible.

${ }^{24}$ A. Marchese y J. Foredellas: Diccionario de retórica. crítica y teminología literaria, Barcelona, Ariel, 1986, p. 396.

${ }^{25}$ Semántica, Madrid, Alianza Universidad, 1977, p. 105 y p. 176.

${ }^{26}$ Semántica, Barcelona, Teide, 1980, p. 362.

27 Ihid., p. 363. 
Lisa Block define los mensajes publicitarios como «variaciones de un lenguaje tautológico» y considera que la aseveración construida con la fórmula «A es igual a $A \gg$ es obstinada y terminante, porque el sujeto sintáctico, al regresar sobre sí mismo, no permite objeciones de ninguna clase: «obviamente no se puede ser diferente de lo que se es $\gg^{28}$. Examinamos algunos ejemplos:

(i) «CITROËN

PRESENTA

UNA NUEVA MARCA:

CITROËN»

(ii) «GORDON`S...

SIEMPRE

GORDON`S».

(iii) «Quorum de Puig. El arte de seducir en silencio. Quorum de Puig».

(iv) «ORION. TODO UN FORD».

(v) «LE BAIN D'ANAÏS. ANAÏS ANAÏS».

(vi) «DIESEL Y ADEMÁS, VOLVO. VOLVO Y ADEMÁS, DIESEL».

(vii) «RENAULT SUPERCINCO. Con todo el espiritu del 5. Pero más cinco que el $5 »$.

En todos los casos se cumple una de las características esenciales de la tautología, la circularidad, puesto que el segundo elemento repite el primero: A se define por A. Se observa, además, la tendencia a la supresión de las formas verbales para que la reflexividad entre el sujeto y el predicado no encuentre los más mínimos obstáculos, ni siquiera gramaticales. Estoexplica el predominio de las construcciones nominales.

Aunque desde el punto de vista de la lógica formal y denotativa sean ciertas las apreciaciones de Lyons en el sentido de que se trata de proposiciones no informativas, desde el punto de vista de la comunicación persuasiva publicitaria, sí entra en funcionamiento un tipo de significación retórica y pragmática en virtud de ciertos mecanismos sugeridores. El análisis que efectúa Lisa Block ${ }^{29}$ desentraña pormenorizadamente los mecanismos a los que nos referimos. En efecto, el primer término A (CITROËN, GORDON'S, QUORUM DE PUIG, RENAULT SUPERCINCO), al aparecer en la cadena sintagmática, cumple la función singularizadora para la personalidad del producto, sin más añadidos conceptuales. Pero, en cambio, al aparecer por segunda vez, ese mismo nombre propio —como

${ }^{27}$ L. Block de Behar : El lenguaje de la publicidad, Buenos Aires, Siglo XXI, 1973, p. 86.

${ }^{24}$ Op. cit. pp. 34-99. 
apunta Lisa Block- se llena de referencias significativas, de esas referencias que se originan a lo largo de toda la formación discursiva, aunque sólo sea por el hecho de que la misma construcción reflexiva recupera y destaca enfáticamente la sustancia material -acústica o gráfica-del significante de la marca. Por otra parte, mediante el procedimiento tautológico entran también en juego retórico las estructuras homofónicas que obviamente se desprenden de la contigüidad de los fonemas, sirviendo de impacto o atracción para el oyente. Lisa Block equipara este efecto al movimiento de retorno que le imprime al verso la disposición de la rima.

Además, el segundo término de la tautología, al ocupar la distribución que se le asigna en el lenguaje no tautológico al constituyente del predicado, inicia de esta forma el proceso de inmersión en el habla, que en ocasiones ha desembocado en la lexicalización de la marca como nombre común.

Estamos, entonces, ante un resorte estilístico para enfatizar el nombre de la marca y para enfatizarla como una aseveración indiscutible, «necesariamente verdadera», en opinión de Lyons. En (iii) la construcción resulta más compleja, porque ocurren dos formas de definición típicamente publicitarias: A es A y A, B, tautología y aposición intercalada. El carácter reversible de A es A permite atribuirle al predicado lo que la aposición le atribuye al sujeto, con lo que el segundo Quorum de Puig significa algo más que el primero. El texto (vii) explicita bien elocuentemente este añadido de significación («Pero más cinco que el $5 »$ ). El slogan (iv) es una tautología implícita en el contexto del anuncio, en el sentido de que la marca y el logotipo de Ford están presentes de múltiples formas en el propio modelo ORION. Es destacable, asimismo, el texto (vi) que inserta la fórmula tautológica acudiendo al recurso de quiasmo.

\section{5. Los datos profesiones sobre el concepto de «marca» publicitaria.}

Este espacio clave que ocupa la marca dentro de las estructuras lingüísticas y organizativas del discurso puede ser documentado, por otra parte, utilizando fuentes e informaciones que suministran las agencias de publicidad. J. Walter Thomson y P. Cooper, publicitarios de empresas farmacéuticas, escriben sobre este tema:

«Una cuestión importante es si tomar un analgésico de marca, en lugar de uno sin marca, puede realmente aumentar el alivio del dolor. Partimos de la hipótesis de que ese efecto se debe a que son mayores la confianza y el valor que añaden a una marca el marketing y la publicidad; si eso es así proporcionará una prueba de la eficacia del sistema de las marcas, al ser realmente capaz de influir en el control mental de los procesos somáticos. Y de hecho así ocurre» ${ }^{30}$.

Este informe se nos muestra especialmente valioso por cuanto se refiere a la comercialización de productos que afectan a la salud de los consumidores, ámbito

${ }^{30}$ Citado por E. Clark: La publicidady su poder. Las técnicas de provocación al consumo, Barcelona, Planeta, 1988, p. 277. 
éste donde debería presuponerse la primacía de la objetividad y el rigor científico frente a las preocupaciones emocionales y subjetivas del marketing. Las palabras de los dos ejecutivos publicitarios son harto elocuentes: hasta en un ámbito como el de la salud y el de la enfermedad funciona discursivamente el prestigio y la simbolización publicitaria del nombre propio. Según las pruebas que aporta el informe, un medicamento con marca aumenta de una cuarta a una tercera parte el alivio del dolor. Lo que, de ser ciertos los datos, quiere decir que la aureola mágica de la marca interactúa como un ingrediente más entre los factores farmacológicos activos. Claro que cabría la posibilidad de que los datos sumnistrados por los citados autores hubieran sido elaborados ficticiamente, como una argucia publicitaria más para atraer cientes anunciantes hacia la empresa que representan. No sería la primera vez que este fenómeno se produce. E. Clark documenta cómo J. Vicary, un investigador de mercados norteamericanos, prefabricó los resultados de su test porque la empresa estaba al borde de la quiebra y pensaba reflotarla de ese modo ${ }^{31}$. De cualquiera de las maneras, sean o no verídicos los datos aportados sobre la influencia de la marca en los productos farmacológicos, el simple hecho de plantearse la discusión indica hasta qué punto el discurso y el producto del discurso están generados y dominados por el nombre propio de la mercancía.

\subsection{Datos estadísticos.}

Para calibrar con más precisión la trascendencia que el nombre propio de la marca adquiere, como síntesis nuclear y principio estructurante de la composición del anuncio, hemos llevado a cabo un análisis estadístico con 728 manifiestos de publicidad estática, distribuidos sectorialmente tal y como se describe en la tabla siguiente. Para ello se han marcado positivamente $(+)$ todos aquellos anuncios que están regidos y dominados por el nombre propio del producto, tanto a nivel de forma como de contenido y lo mismo a nivel icónico que lingüístico. Es decir, incluimos en esta serie: los anuncios que están construidos «en infinitivo» y, finalmente, aquellos cuya marca, logotipo o el referente representado se imponen claramente frente al destinatario y frente al destinador. De este modo, puede ilustrarse cuantitativamente el papel que desempeña en el discurso la instalación del producto como marca comercial y, en consecuencia, como imagen de marca:

${ }^{31}$ Ibid., p. 157. 


\begin{tabular}{|l|r|r|c|}
\hline & & + & $\%$ \\
\hline 1. Automoción & 138 & 55 & 39,85 \\
2. Bebidas & 151 & 73 & 48,34 \\
3. Complementos & 37 & 22 & 59,45 \\
4. Cosmética & 53 & 25 & 47,16 \\
5. Finanzas & 32 & 41 & 2,50 \\
6. Hogar & 112 & 22 & 19,64 \\
7. Informática & 25 & 5 & 20,00 \\
8. Instituciones & 48 & 0 & 0 \\
9. Moda & 46 & 18 & 39,13 \\
10. Navidad & 33 & 11 & 33,00 \\
11. Tabaco & 23 & 83 & 4,78 \\
12. Viajes y ocio & 30 & 1 & 3,33 \\
\hline TOTALES & 728 & 244 & 33,51 \\
\hline
\end{tabular}

Los anteriores datos muestran algunas tendencias dominantes en el sistema publicitario de los textos examinados:

a) El alto porcentaje $(33,51 \%)$ de anuncios marcados positivamente por la tendencia a una publicidad dominada absolutamente, icónica o linguiísticamente, por el actante-producto y su nombre propio. Tal dominio se acrecienta aún más, si tenemos en cuenta que en el 66,49\% restante ha de estar presente también, de una u otra manera, el producto comercial y su marca respectiva.

b) Los sectores que sobrepasan el porcentaje medio son por orden ascendente: tabaco $(34,78 \%)$, moda $(39,13 \%)$, automoción $(39,85 \%)$, cosmética $(47,16 \%)$, bebidas $(48,34 \%)$ y complementos $(59,45 \%)$. Precisamente, el lugar destacado que ocupa la serie de los complementos, con 25,94 puntos más que la media del toatal, se debe al hecho de que los productos incluidos como complementos (relojes, joyas, objetos de escritura, regalos, etc.) experimentan una fuerte tendencia a la publicidad esencialista «en infinitivo».

c) En el extremo opuesto, encontramos el sector de viajes y ocio $(3,33 \%)$ y la publicidad institucional con total ausencia de manifiestos dominados por la marca o firma. Obviatnente, las instituciones públicas (municipios, ministerios, campañas de limpieza, consejos de tráfico, etc.) están menos acuciados por la necesidad de mostrar la marca que los productos o servicios comerciales y directamente competitivos. Lo que no significa, desde luego, que no aparezcan nombre propios o logotipos en esta publicidad insititucional.

\section{Interpretaciones y consecuencias.}

La interpretación de los datos acumulados en los apartados anteriores, tanto los extraídos del interior del discurso como los aportados exteriormente por las 
empresas de publicidad, nos permiten establecer una correspondencia entre la asignación del nombre propio al producto y la adquisición de la modalidad virtualizante que va a permitir a la mercancía instaurarse como actante del programa persuasivo.

Evidentemente, la simbolización ritual, presupuesta en el acto nominativo publicitario, es un requisito previo para investir (discursivamente) la mercancía de un conjunto de valores descriptivos que la conformen (semióticamente) como actante competente, es decir, como actante susceptible de ejercer una cierta actividad seductora específicamente dirigida a suscitar, primero, y a controlar, después, los impulsos estimulantes de la persuasión. Se trata, en definitiva, de transformar la naturaleza meramente económica de la mercancía en naturaleza semiótica: la materia económica recibe la investidura del signo. Es y funciona como signo. Lo que significa la cualificación del producto industrial como el actante específico del objeto del deseo.

Para ejercer los poderes del signo del deseo, el nombre propio de la marca o firma comercial necesita configurar ese concepto que los publicistas denominan «imagen de marca» que le confiere al producto un carácter «personal» en el discurso sin que haya de tener correspondencia con la realidad empírica. Dicho tratamiento discursivo rescata a la mercancía del anonimato en que estaba necesariamente sumida en el sistema de producción en serie.

Nos encontramos, pues, ante una de las operaciones más decisivas de la publicidad como así lo reconocen sus propios profesionales e investigadores. Aleardo Buzzi, presidente para Europa de los cigarrillos MARLBORO, ha declarado: «Somos !a marca número uno del mundo. Lo que queremos es promocionar una imagen particular de aventura, de valor, de virilidad...». Y Joel S. Dubon, gerente de investigación de comunicaciones de Coca-Cola, definió en 1984 a I. Pavlov como «el padre de la publicidad moderna»: «El estímulo no condicionado de Pavlov consistía en un espray de polvo de carne que producía salivación... Pero si se profundiza en lo que hizo Pavlov, lo que en realidad ocurrió es que tomó un objeto neutral y, asociándolo a otro muy significativo, lo convirtió en el símbolo de una cosa diferente; le insufló imaginación, le dio un valor añadido. ¿Y Y no es precisamente eso lo que intentaremos hacer en las modernas imágenes publicitarias? $\gg^{32}$.

Se desprende de estas opiniones que el concepto publicitario de «imagen de marca», además de como elemento individualizador del producto, actúa como elemento de predicación de los atributos, de las significaciones simbólicas y de los programas narrativos que la marca proyecta como promesas:

«La marca del León simboliza la fuerza, el prestigio, la seguridad, la experiencia y la eficacia»: (PEUGEOT).

De este modo, el receptor del mensaje es situado frente a esos rasgos sémicos de la «personalidad» de la marca que hacen aparecer como distintas a mercancías que son,

\footnotetext{
32 Ambas citas, la de Buzzi y la de Dubon, están tomadas de E. Clark, op. cit., p. 313 y p. 85 respectivamente.
} 
muchas veces, cualitativamente idénticas. Las agencias publicitarias construyen esa figura fundamentalmente predicativa de la «imagen de marca» para singularizar discursivamente al producto. $Y$ decimos discursivamente porque, en la realidad exterior al texto, los productos que se promocionan dentro de la misma gama o sector competitivo poseen generalmente los mismos referentes objetivos. Este es el caso que explica Marcus-Steiff ${ }^{33}$ al referirse a las distintas «imágenes» que intentan trasmitir en su publicidad las entidades bancarias, cuando en realidad el tipo de interés es el mismo o varía de una forma apenas significativa. La convención enunciativa que nos proponen los enunciados hace creíbles cualquier tipo de connotaciones positivas, aunque objetivamente poco o nada tengan que ver con los «valores de usos» inherentes a tal o cual producto del mercado. La materialidad empírica del objeto se comprime y deviene elemento secundario.

La instancia predicativa y metafórica de la «imagen de marca» nos remite de nuevo al debatido conflicto de la significación de los nombres propios, que alcanza su manifestación más polémica en las teorías de J. S. Mill y O. Jespersen. Si el primero establece que la «función denotativa» de los nombres propios se opone a la «función connotativa» de los nombres comunes, el segundo invierte estas afirmaciones, para sostener que «los nombres propios (tal como se usan de hecho) connotan el mayor número de atributos ${ }^{34}$. Ullman entra en la polémica partiendo de la distinción entre lengua y habla, para concluir que, desde el punto de vista de la situación contextual de los interlocutores que usan la lengua, los nombres propios sí admiten las connotaciones, mientras que desgajados de su contexto únicamente significan la identificación del objeto nominado. U. Eco, para definir la denotación desde una perspectiva semiótica, interviene en el problema exigiendo también la situación contextual como la condición a un sistema connotativo ${ }^{35}$. Justamente, lo que ocurre en la publicidad, a causa del pacto enunciativo impuesto por las condiciones de recepción, es que la realización del discurso se lleva a cabo desde una situación lingüística y contextual bien delimitada, en la que los interlocutores están en posesión de los códigos a que han de recurrir para cifrar y descifrar el mensaje: no se trata de un código científico abstruso y neutro, ni de un nombre propio hipotéticamente atribuido a algo o alguien desconocido. Al menos en la publicidad no queda, por tanto, más opción que admitir los valores connotativos que acompañan al nombre de la marca, como revela con claridad el concepto mismo de «imagen de marca».

Precisamente, porque existen la figura de la marca y la figura de la «imagen de la marca», podemos sostener que en el lenguaje de la publicidad ocurren simultáneamente las dos maneras de significación que Todorov señala para los nombres propios: «En primer lugar tienen un sentido, que consiste en indicar a qué clase de objetos pertenece el individuo designado (...) En segundo término los

${ }^{33}$ «A propos des effets de la publicité sur les ventes», en Les mythes de la publicité, Communications, $\mathrm{n}^{\mathrm{0}} 17,1971$, p. 20.

${ }^{34}$ Citamos por S. Ullman (op. cit., pp: 84-85), quien recupera la polémica cuando examina su criterio número tres ( «Denotación contra connotación») para caracterizar los nombres propios.

${ }^{35}$ Cf. La estructura ausente, Barcelona, Lumen, 1981, pp: 115. 
nombres propios reciben inmediatamente significaciones asociadas (connotaciones, en un sentido no lógico) ${ }^{36}$.

Puesto que hemos descrito ya las razones por las que una mercancía cualquiera, producida en serie para ser consumida en serie, es sometida al rito bautismal de la imposición de un nombre propio con la consiguiente atribución de la «imagen de marca», habrá que ver ahora mediante qué investidura discursiva el referente del objeto económico ejecuta su función actancial de objeto del deseo, es decir, cómo despliega su actividad de seducción hacia el destinatario del mensaje ${ }^{37}$. Y puesto que, además, no cabe duda de que la publicidad contemporánea disfraza sus proyectos persuasivos mediantes actos ilocucionarios seductores, es necesario que la marca reciba un tratamiento análogo al de la persona, un tratamiento que la rescata del anonimato cosificador en que estaba sumida la mercancía en el sistema de producción industrial en serie.

Por lo tanto, las operaciones textuales o icónicas de semiotización del referente van encaminadas a asignarle al producto una naturaleza antropomórfica, como requisito para que las cosas puedan realizar transformaciones que corresponden a los hombres y hacerse así mucho más deseables. De otro modo, las promesas de competencia para seducir a los clientes potenciales verían mermada su fuerza expresiva. La personalidad adquirida por la marca comercial es un concepto semiótico que se configura como tal durante el itinerario antropocéntrico que recorren las mercancías, desde que son producidas hasta que son consumidas. En este sentido, hay cierta similitud entre la publicidad y algunos relatos - sobre todo, etnoliterarios - caracterizados por una inspiración antropomórfica, en la medida en que atribuyen el estatuto del sujeto del hacer a cosas o a seres inanimados.

Dentro de esta orientación subjetivizadora resulta explicable que el FORD FIESTA sea «un español que ha triunfado en Alemania», o que el SIERRA sea «un coche inteligente», oque el TALBOT SAMBA nos «esté esperando para divertimos», o que se celebre en algún lugar de Europa una «cumbre europea» y esté presidida por tres modelos RENAULT, o que el ALFA ROMEO esté dotado de «nervio y carácter», o que el SEAT IBIZA II represente «una nueva generación con fuerza interior y que avanza con seguridad» porque «bajo su capot hay un corazón que acelera las sensaciones». Y, por fin, que alguien hable con el PEUGEOT 205 para irse con él «al fin del mundo», o que el RENAULT SUPERCINCO se decida él mismo a hablarnos: «Mirame. Verás que línea. Descúbreme. Por supuesto, te puedo hablar de asientos pétalo (...), de mi tablero (...). Vente a verme y a probarme.

Es cierto que este discurso antropomorfizado se muestra de forma más palpable en el automóvil que en otros sectores del mercado. Pero es que el automóvil es el objeto-símbolo por excelencia, destinado ejemplarmente a entablar comunicación directa con el consumidor. Sin embargo, también otros muchos productos recurren

${ }^{36}$ Gramática del Decamerón, Madrid, J.B., 1973, pp: 51.

${ }_{37}$ «En la economía de la abundancia nos resulta muy a menudo posible escoger en función de los significados secundarios que los productos tienen para nosotros. En este respecto la tendencia al antropomorfismo, que nos empuja a asociar significados psicológicos a objetos inanimados, es muy fuerte». Delbecque, N. y Leuven, K.U.: Op. cit., pp: 203. 
a personificaciones similares para impresionar directamente la intimidad del interlocutor. Las prendas de moda son «prendas de imaginación» y NESCAFÉ, que nos desea felicidad y paz en Navidad, puede ser recibido como un amigo que nos visita: «Bienvenido al hogar, Tú, café solo, que eres aroma y sabor, cuerpo y olor... bienvenido al hogar». Ya hemos visto como THOMSON y SABA entraban a formar parte de los grandes maestros de la música. Un «frigorífico», «importado de Alemania», se dirige en estos términos al ama de casa: «soy muy conservador»; y una lavadora de la misma marca, ya no sólo se dirige al ama de casa, sino que le pide prestada hasta su palabra: «SOY INTRANSIGENTE. No soporto que quede ni rastro de mancha. No resisto que se maltrate la ropa. $Y$ me pone enferma que se derroche energía. Lo confieso: soy intransigente».

Otras veces las técnicas de la personificación utilizan algunos procedimientos más sutiles, como la voz ominisciente de un narrador exterior que se muestra buen conocedor de la materia sobre la que habla:

«LAS CEPAS [...] son las cepas del vino de Jerez [...] Las dos igual de sensibles, de delicadas. Las dos igual de sabias... [...] A su muerte — casi la de un ser queridola viña queda yerma durante cinco años. Hay que esperar otros cinco años para que la cepa, de nuevo moza aguerrida, rinda su fruto. DOMECQ. Cosecha de la tierra».

En otras ocasiones, el narrador deja oír su voz desde dentro de anuncio, como protagonista de la historia:

«Marie, el sueño de una noche de verano: El sabor de Marie deja huella. Quien llega a conocer a fondo, sabe que su compañía crea un clima cálido y confortable, un ambiente estimulante y original. Porque ella, Marie, es suave y enérgica a la vez, agradable y con una atractiva personalidad, imposible de olvidar». (MARIEBRIZARD, Woody Allen y una atractiva mujer son los personajes de la escena).

Las operaciones que acabamos de describir - tanto la asignación de un nombre propio como la construcción de la «imagen de marca»-, en la medida en que desplazan del proceso significativo los «valores de uso» del producto en favor de los «valores de cambio» añadidos, consiguen que el referente de la mercancía sobresignifique su mera existencia, cuando en sí mismo no debería expresar sino su utiliaiad funcional y práctica. De la comunicación meramente documental e informativa se ha producido el salto cualitativo a una comunicación regida por la afectividad y la expresión retórica. El utensilio se rodea, así, de profundidad pasional y simbólica frente a la descripción aséptica de un acercamiento documentalista y objetivo. En el documental se habla de las cosas, en la publicidad de lo que rodea a las cosas. El objeto, que pierde gran parte de su naturaleza pragmática, se recubre de la naturaleza semántica del signo. Y en el límite del proceso es signo en lugar de objeto:

(i) «Déjate seducir por el carácter abierto y atrevido de Vodka Eristoff» (no por el vodka, sino por su carácter).

(ii) «Gran Duque de Alba, símbolo de grandeza». 
(iii) «PERSONALIDAD WHITE LABEL».

(iv) «Tener Magno es todo un símbolo».

(v) «OLD SPICE. La huella de un hombre».

(vi) «La recomendación: Montblanc habla por sí mismo y por usted».

(vii) «Todos ellos (los motores) son signos de que este coche va a cambiar la historia del automóvil».

(viii) «Ford Granada Ghía. Signo de admiración».

El discurso publicitario, por medio de esta semiotización del referente, se está convirtiendo en uno de los lenguajes fundamentales de la sociedad actual, con una tendencia acelerada a instituirse como instrumento de reconocimiento de las cosas: la colonia MASSIMO DUTTI propone un reconocimiento de sí misma como producto por su carácter; pero, al mismo tiempo, propone un reconocimiento del hombre que la usa a través de los valores descriptivos que predica el carácter de la marca: «carácter al máximo». Lo que viene a significar que el producto no solamente adquiere una personalidad a través de su «imagen de marca», sino que además transmite y crea la imagen del destinatario: «CANONFAX (...) ya puedes trasmitir imagen... Tu imagen. CANON CUIDA TU IMAGEN».

Finalmente, la importancia de nominar individualizadoramente el producto se deja ver en el hecho de que existan manifiestos como el siguiente, cuyo único argumento es, precisamente, el acto virtualizante de la denominación misma:

\author{
«I. C. WATCHES \\ con \\ NOMBRE Y APELLIDOS \\ Un reloj único \\ Con nombre propio. El suyo. Suizo \\ Corazón de Cuarzo. Exclusivo. \\ Para saber el tiempo \\ al segundo. Cada día. \\ Déle nombre».
}

No fortuitamente el mensaje subrayado de este anuncio se corresponde, bajo una simetría casi perfecta, con la teoría de J. Lacan sobre el poder nombrar los objetos para estructurar la percepción misma. El nombre y los apellidos del producto se manifiestan como imprescindibles para percibir el tiempo: «El percipi del hombre no puede sostenerse sino en el interior de una zona de nominación. Mediante la nominación el hombre hace que los objetos subsistan en una cierta consistencia (...) El nombre es el tiempo del objeto ${ }^{38}$. Aplicando las ideas de Lacan al anuncio que nos ocupa, el nombre propio - IC. Watches-es una especie de contrato convenido entre destinador y destinatario para darle existencia y reconocimiento al objeto anónimo. Probablemente, la desaparición del nombre propio de la marca conllevaría la desaparición de la cosa nominada.

${ }^{38}$ El Seminario H: El yo en la teoría de Freud y en la técnica psicoanalítica, Barcelona, Paidós, 1983 , pp: 257 . 